ㄷ О. О. Палюх, к.т.н., доцент, КПІ ім. Ігоря Сікорського, Київ, Україна

\title{
ЕКСПЕРИМЕНТАЛЬНЕ ВИЗНАЧЕННЯ МІЦНОСТІ СКЛЕЄНИХ ЗРАЗКІВ ПАПЕРУ ТА КАРТОНУ ДЛЯ ВИГОТОВЛЕННЯ КНИЖКОВО-ЖУРНАЛЬНИХ ОБКЛАДИНОК І ПАЛІТУРОК РІЗНИХ КОНСТРУКЦІЙ
}

Враховуючи необхідність виготовлення ресурсозберігальних та ергономічних книжково-журнальних обкладинок у сучасному високо конкурентному середовищі розповсюдження поліграфічної продукції та формування споживчої ціни, аналіз проведених досліджень визначив залежності змін у міцності одиничних, подвійних та склеєних зразків палітурних матеріалів, що мають прикладне значення при підбиранні компонентів виготовлення оправ з мінімізованими економічними показниками.

Ключові слова: книжкові оправи; палітурка; обкладинка; зусилля розтягування; міцність матеріалів; руйнування зразків.

\section{Постановка проблеми}

Завданням експериментального дослідження міцності склеєних зразків паперу та картону, що застосовуються для виготовлення книжково-журнальних обкладинок і палітурок є визначення цифрових показників, на підставі яких можливо здійснювати вибір конструкцій обкладинок, що сприяють підвищенню міцності, довговічності та експлуатаційних характеристик оправ. Виявлені результати покладені в основу практичних рекомендацій можливих варіантів поєднання при застосуванні окремих видів паперу, картону та палітурних клеїв, які найбільше використовують для виготовлення книжкових обкладинок і палітурок різних конструкцій масовими тиражами.

\section{Аналіз попередніх} досліджень

Відомі конструкції обрізних паперових обкладинок для звичайного криття книжкових і журнальних блоків, які конструктивно складаються з одного аркуша паперу, який накидають на блок і приклеюють середньою частиною до корінця блоку, а також обкладинки для криття врозпуск, які приклеюють не тільки до корінцевої частини блоку, але й до крайніх аркушів блоку по смузі 5-8 мм від корінця [1]. Недоліки (швидке розтріпування, згинання обрізів, стирання кантів) впливають на тривалість використання таких обкладинок. А залишкова деформація на ко-

(c) $2017 \mathrm{p}$. 
рінці обкладинки при розкриванні книги призводить до швидкої втрати її товарного вигляду [1].

Також відомі конструкції обрізних обкладинок, у яких аркуш обрізної обкладинки, доповнений одним клапаном, загнутим назовні по передньому полю, огортає першу сторінку й корінець обкладинки та приклеєний уздовж корінцевих згинів на сторінки обкладинки по смузі шириною 5-8 мм. У таких обкладинок подвійна перша сторінка, подвійний корінець і одинарна друга частина обкладинки [2].

Знайшли широке використання обкладинки, у яких конструкція простої обрізної обкладинки доповнена загнутими всередину двома клапанами по передньому обрізу блоку, у яких ширина клапанів перевищує ширину сторінок обрізної обкладинки на ширину корінцевої частини блоку. Кінці клапанів приклеєні до корінця блоку, а сама обкладинка, що складається із однієї деталі, у якої подвійна товщина корінця, подвійна товщина першої і другої сторінок обкладинки, приклеєна по обидва боки корінця блоку по смугах шириною 5-8 мм. Основними властивостями таких обкладинок $є$ їх подвійна товщина в корінцевій частині та подвійна товщина першої та другої частин обкладинок [3].

Прості обкладинки 3 однієї деталі (Full-Flaps, Integraldeck) й ускладнені - з однієї деталі (обкладинки з клапанами) [4] $€$ обкладинками, що вирубуються або вирізаються з цілого аркуша картону, хромерзацу, щільного паперу чи іншого палітурного матеріалу. На відміну від обрізної такі обкладинки мають на верхньо- му, нижньому та передньому полях крайки шириною 5-15 мм, загнуті та приклеєні в середину обкладинки, або замість крайок на передньому полі обкладинки загнуті клапани, що за розмірами менші за ширину обкладинок. Одинична товщина палітурного матеріалу, із якого виготовляються обкладинки, за рахунок загнутих і приклеєних крайок зміцнюється в контурній частині обкладинки [5].

Вивченню особливостей поліграфічних матеріалів, дослідженню палітурних клеїв [6], умов їх використання в технологічних процесах з виготовлення книжкових оправ та іншим вимогам сполучення «палітурний матеріал + клей» присвячені роботи українських та іноземних учених Лазаренка Е. Т., Гавенко С. Ф., Мартинюк М. С., Розума О. Ф., Величко О. М., DinnerW., Engeler H., Furler A., Sendor М. тощо. Результати досліджень частково застосовані в державних стандартах, що стосуються поліграфічного виконання [7] та показників якості обкладинок і палітурок [8].

Iз врахуванням перелічених особливостей деяких конструкцій книжково-журнальних обкладинок і сучасних можливостей в добиранні матеріалів для їх виготовлення, широких можливостей застосування різноманітних брошурувально-палітурних клеїв, моделювання варіантів їх технологічного поєднання (на підставі об'єктивних показників міцності) систематизовано вибір зразків різних конструкцій оправ.

\section{Мета роботи}

Визначення показників міцності зразків палітурних матеріалів 
з різними технологічними властивостями, які використовують для виготовлення простих і ускладнених обкладинок із метою отримання порівняльних результатів випробувань на міцність одиничних зразків, подвійних зразків без проклеювання та подвійних зразків, склеєних окремими видами клеїв, які використовують у палітурному виробництві [9]. Перелік відібраних для дослідження зразків палітурних матеріалів відповідає основним конструкціям обкладинок, виготовлених із однієї деталі 3 різними конструктивними особливостями, що, завдяки різній геометрії відтворення, впливають на тривалість використання та товарний вигляд [10].

\section{Результати проведених досліджень}

Для визначення показників міцності зразків палітурних матеріалів для створення простих i складних обкладинок, що можуть бути конструктивно виготовлені з одного аркуша матеріалів із різними технологічними властивостями [11], необхідно визначити максимальні зусилля, при яких відбувається руйнування одиничних, подвійних та склеєних подвійних зразків під час розтягування їх на розривній машині.

Для проведення досліджень були використані клеї: PLAKAL Batch 6602 (Німеччина), термоклей Tecnomelt 3660 (Німеччина), термоклей Swift therm 8026 (Фінляндія), дисперсія полівінілацетатна ПВАД 51-П (Україна), дисперсія полівініл-ацетатна ПВАД ДФ-51/15В (Україна) [12]. Для визначення зусиль, що призводять до руйнування та роз- риву зразків було застосовано такі матеріали: крейдований папір масою 130, 150, 170, 250, 300, $350 г / \mathrm{M}^{2}$ та картон хром-ерзац (chrome-erzac) товщиною 0,3 мм.

Експериментальні дослідження виконувалися на розривній машині РМБ-30 з граничним навантаженням не менше $50 \mathrm{H}$ (5 кГс), ціною поділки шкали А не більше 0,02 кГс та вантажем, що створює зусилля на розрив близько 0,001 МПа $\left(0,01 \mathrm{\kappa} Г \mathrm{c} / \mathrm{cm}^{2}\right)$.

Зразки, призначені для випробовування, - це смужки перелічених матеріалів довжиною 100 мм і шириною 15 мм: одиничні, подвійні без склеювання та подвійні склеєні між собою палітурними клеями, відібраними для експериментів.

Отримані результати максимальних зусиль руйнування окремих поліграфічних матеріалів під час розтягування зразків та розрахована міцність під час розтягування відтворені в табл. 1 .

Враховуючи велику різноманітність обкладинок, що виготовлюються із однієї заготовки аркуша щільного паперу чи тонкого картону, типу хром-ерзац, які у готовому вигляді являють собою один обрізний аркуш палітурного матеріалу, або один аркуш із загнутими і приклеєними до внутрішньої частини обкладинки вузькими крайками, або конструкція передбачає подвійний аркуш обкладинки, обрізаний по верхньому та нижньому полю [2, 3], експериментальні вимірювання, перш за все, мали на меті визначити відмінності між показниками міцності під час розтягування одиничних та подвійних зразків матеріалів, які згідно 3 
Таблиця 1

Результати максимальних зусиль руйнування окремих поліграфічних матеріалів під час розтягування зразків та міцність під час розтягування

\begin{tabular}{|c|c|c|c|c|c|c|c|c|c|}
\hline \multirow{3}{*}{$\begin{array}{l}\text { № } \\
\Pi / \Pi\end{array}$} & \multirow{3}{*}{$\begin{array}{c}\text { Назва } \\
\text { матеріалу }\end{array}$} & \multirow{3}{*}{$\begin{array}{c}\text { Назва } \\
\text { клею }\end{array}$} & \multicolumn{5}{|c|}{ Руйнівне зусилля, кГс } & \multirow{3}{*}{$\begin{array}{c}\text { Сере- } \\
\text { днє } \\
\text { всіх } \\
\text { зраз- } \\
\text { ків, } \\
\text { кГс }\end{array}$} & \multirow{3}{*}{$\begin{array}{c}\text { Міц- } \\
\text { ність } \\
\text { під час } \\
\text { розтя- } \\
\text { гуван- } \\
\text { ня, } \\
\text { КГс/см }\end{array}$} \\
\hline & & & \multicolumn{5}{|c|}{ Номер зразків } & & \\
\hline & & & 1 & 2 & 3 & 4 & 5 & & \\
\hline 1.1 & $\begin{array}{l}\text { Папір крейдований } \\
130 \text { г/м² - одиничний } \\
\text { зразок }\end{array}$ & Без клею & 5,1 & 5,1 & 5,3 & 5,2 & 5,3 & 5,2 & 3,5 \\
\hline 1.2 & $\begin{array}{l}\text { Папір крейдований } \\
130 \text { г/м² - подвійний } \\
\text { зразок }\end{array}$ & Без клею & 9,7 & 9,7 & 9,5 & 9,5 & 9,6 & 9,6 & 6,4 \\
\hline 1.3 & $\begin{array}{l}\text { Папір крейдований } \\
130 \text { г/м² - склеєний } \\
\text { зразок }\end{array}$ & $\begin{array}{c}\text { PLAKAL } \\
\text { Batch } 6602\end{array}$ & 11,1 & 10,8 & 11,2 & 10,8 & 11,1 & 11,0 & 7,33 \\
\hline 1.4 & $\longrightarrow »$ & $\begin{array}{c}\text { Термоклей } \\
\text { Tecnomelt } 3660\end{array}$ & 11,9 & 12,1 & 11,5 & 12,0 & 11,5 & 11,8 & 7,87 \\
\hline 1.5 & $-\gg-$ & $\begin{array}{c}\text { Термоклей Smift } \\
\text { therm } 8028\end{array}$ & 11,3 & 11,9 & 11,3 & 11,7 & 11,8 & 11,6 & 7,73 \\
\hline 1.6 & -»- & $\begin{array}{c}\text { ПВАД ДФ } \\
51 / 15 В\end{array}$ & 13,1 & 12,9 & 13,2 & 12,8 & 13,0 & 13,0 & 8,67 \\
\hline 1.7 & -»- & ПВАД 51-П & 11,6 & 11,7 & 11,1 & 11,5 & 11,4 & 11,4 & 7,60 \\
\hline 2.1 & $\begin{array}{l}\text { Папір крейдований } \\
150 \text { г/м² - одинич- } \\
\text { ний зразок }\end{array}$ & Без клею & 5,3 & 5,4 & 5,8 & 5,3 & 5,7 & 5,5 & 3,67 \\
\hline 2.2 & $\begin{array}{l}\text { Папір крейдований } \\
150 \text { г/м² - подвійний } \\
\text { зразок }\end{array}$ & Без клею & 10,9 & 10,8 & 10,7 & 10,7 & 10,9 & 10,8 & 7,2 \\
\hline 2.3 & $\begin{array}{l}\text { Папір крейдований } \\
150 \text { г/м² - склеєний } \\
\text { зразок }\end{array}$ & $\begin{array}{c}\text { PLAKAL } \\
\text { Batch } 6602\end{array}$ & 12,1 & 12,3 & 12,3 & 12,1 & 12,2 & 12,2 & 8,13 \\
\hline 2.4 & -»- & $\begin{array}{c}\text { Термоклей } \\
\text { Tecnomelt } 3660\end{array}$ & 13,1 & 12,7 & 12,9 & 13,2 & 13,1 & 13,0 & 8,67 \\
\hline 2.5 & -»- & $\begin{array}{c}\text { Термоклей Smift } \\
\text { therm } 8028\end{array}$ & 12,8 & 12,5 & 12,6 & 13,0 & 13,1 & 12,8 & 8,53 \\
\hline 2.6 & -»- & $\begin{array}{c}\text { ПВАД ДФ } \\
51 / 15 B\end{array}$ & 14,3 & 14,0 & 14,3 & 14,1 & 14,3 & 14,2 & 9,47 \\
\hline 2.7 & -»- & ПВАД 51-П & 13,2 & 13,4 & 13,2 & 13,4 & 13,3 & 13,3 & 8,87 \\
\hline 3.1 & $\begin{array}{l}\text { Папір крейдований } \\
170 \text { г/м² - одинич- } \\
\text { ний зразок }\end{array}$ & Без клею & 8,0 & 7,7 & 7,7 & 8,1 & 8,0 & 7,9 & 5,27 \\
\hline 3.2 & $\begin{array}{l}\text { Папір крейдований } \\
170 \text { г/м² - подвійний } \\
\text { зразок }\end{array}$ & Без клею & 14,9 & 14,9 & 15,1 & 14,7 & 14,9 & 14,9 & 9,93 \\
\hline 3.3 & $\begin{array}{l}\text { Папір крейдований } \\
170 \text { г/м² - склеєний } \\
\text { зразок }\end{array}$ & $\begin{array}{c}\text { PLAKAL } \\
\text { Batch } 6602\end{array}$ & 16,4 & 16,1 & 16,4 & 16,1 & 16,5 & 16,3 & 10,87 \\
\hline
\end{tabular}


Продовження табл. 1

\begin{tabular}{|c|c|c|c|c|c|c|c|c|c|}
\hline \multirow{3}{*}{$\begin{array}{l}\text { № } \\
\Pi / \Pi\end{array}$} & \multirow{3}{*}{$\begin{array}{c}\text { Назва } \\
\text { матеріалу }\end{array}$} & \multirow{3}{*}{$\begin{array}{l}\text { Назва } \\
\text { клею }\end{array}$} & \multicolumn{5}{|c|}{ Руйнівне зусилля, кГс } & \multirow{3}{*}{$\begin{array}{c}\text { Сере-- } \\
\text { днє } \\
\text { всіх } \\
\text { зраз- } \\
\text { ків, } \\
\text { кГс }\end{array}$} & \multirow{3}{*}{$\begin{array}{c}\text { Міц- } \\
\text { ність } \\
\text { під час } \\
\text { розтя- } \\
\text { гуван- } \\
\text { ня, } \\
\text { КГс/см }\end{array}$} \\
\hline & & & \multicolumn{5}{|c|}{ Номер зразків } & & \\
\hline & & & 1 & 2 & 3 & 4 & 5 & & \\
\hline 3.4 & $\longrightarrow »$ & $\begin{array}{c}\text { Термоклей } \\
\text { Tecnomelt 3660 }\end{array}$ & 17,1 & 17,2 & 17,1 & 17,0 & 17,1 & 17,1 & 11,4 \\
\hline 3.5 & -»- & $\begin{array}{c}\text { Термоклей Smift } \\
\text { therm } 8028\end{array}$ & 17,0 & 17,1 & 16,7 & 16,7 & 17,0 & 16,9 & 11,27 \\
\hline 3.6 & -»- & $\begin{array}{c}\text { ПВАД ДФ } \\
51 / 15 В\end{array}$ & 18,4 & 18,2 & 18,1 & 18,4 & 18,4 & 18,3 & 12,2 \\
\hline 3.7 & $\longrightarrow »-$ & ПВАД 51-П & 17,2 & 17,2 & 17,2 & 17,3 & 17,1 & 17,2 & 11,47 \\
\hline 4.1 & $\begin{array}{l}\text { Папір крейдований } \\
250 \text { г/м²- одинич- } \\
\text { ний зразок }\end{array}$ & Без клею & 11,9 & 12,4 & 12,4 & 11,9 & 11,9 & 12,10 & 8,07 \\
\hline 4.2 & $\begin{array}{l}\text { Папір крейдований } \\
250 \text { г/м² - подвійний } \\
\text { зразок }\end{array}$ & Без клею & 16,8 & 16,7 & 16,8 & 16,7 & 16,8 & 16,76 & 11,17 \\
\hline 4.3 & $\begin{array}{l}\text { Папір крейдований } \\
250 \text { г/м² - склеєний } \\
\text { зразок }\end{array}$ & $\begin{array}{c}\text { PLAKAL } \\
\text { Batch } 6602\end{array}$ & 17,9 & 18,0 & 17,9 & 18,1 & 18,2 & 18.02 & 12,01 \\
\hline 4.4 & $\longrightarrow »-$ & $\begin{array}{c}\text { Термоклей } \\
\text { Tecnomelt } 3660\end{array}$ & 18,8 & 19,0 & 18,9 & 19,1 & 19,2 & 19,0 & 12,60 \\
\hline 4.5 & $\longrightarrow »-$ & $\begin{array}{c}\text { Термоклей Smift } \\
\text { therm } 8028\end{array}$ & 18,7 & 18,7 & 18,8 & 18,8 & 18,9 & 18,78 & 12,52 \\
\hline 4.6 & $\longrightarrow »-$ & $\begin{array}{c}\text { ПВАД ДФ } \\
51 / 15 \mathrm{~B} \\
\end{array}$ & 20,2 & 20,2 & 20,3 & 20,2 & 20,3 & 20,24 & 13,49 \\
\hline 4.7 & $-»-$ & ПВАД 51-П & 20,0 & 19,9 & 19,9 & 19,8 & 20,0 & 19,92 & 13,28 \\
\hline 5.1 & $\begin{array}{l}\text { Папір крейдований } \\
300 \text { г/м² - одинич- } \\
\text { ний зразок }\end{array}$ & Без клею & 15,7 & 15,7 & 15,8 & 15,8 & 15,9 & 15,78 & 10,52 \\
\hline 5.2 & $\begin{array}{l}\text { Папір крейдований } \\
300 \text { г/м² - подвійний } \\
\text { зразок }\end{array}$ & Без клею & 18,4 & 18,5 & 18,6 & 18,5 & 18,5 & 18,5 & 12,33 \\
\hline 5.3 & $\begin{array}{l}\text { Папір крейдований } \\
300 \text { г/м² - склеєний } \\
\text { зразок }\end{array}$ & $\begin{array}{c}\text { PLAKAL } \\
\text { Batch } 6602\end{array}$ & 19,9 & 19,8 & 19,9 & 19,7 & 19,8 & 19,82 & 13,21 \\
\hline 5.4 & $\longrightarrow »-$ & $\begin{array}{c}\text { Термоклей } \\
\text { Tecnomelt } 3660\end{array}$ & 20,8 & 20,8 & 20,9 & 20,9 & 20,9 & 20,84 & 13,89 \\
\hline 5.5 & $\longrightarrow »-$ & $\begin{array}{c}\text { Термоклей Smift } \\
\text { therm } 8028\end{array}$ & 20,6 & 20,6 & 20,7 & 20,8 & 20,7 & 20,68 & 13,79 \\
\hline 5.6 & $\longrightarrow »-$ & $\begin{array}{c}\text { ПВАД ДФ } \\
51 / 15 B\end{array}$ & 23,7 & 23,6 & 23,7 & 23,8 & 23,6 & 23,68 & 15,79 \\
\hline 5.7 & $\longrightarrow »-$ & ПВАД 51-П & 24,0 & 24,1 & 24,2 & 24,0 & 24,3 & 24,12 & 16,08 \\
\hline 6.1 & $\begin{array}{l}\text { Папір крейдований } \\
350 \text { г/м² - одинич- } \\
\text { ний зразок }\end{array}$ & Без клею & 14,4 & 14,0 & 14,4 & 14,3 & 14,4 & 14,3 & 9,53 \\
\hline
\end{tabular}




\section{ТЕХНОЛОГІчн ПРОЦЕСИ}

Закінчення табл. 1

\begin{tabular}{|c|c|c|c|c|c|c|c|c|c|}
\hline \multirow{3}{*}{$\begin{array}{l}\text { № } \\
\Pi / \Pi\end{array}$} & \multirow{3}{*}{$\begin{array}{c}\text { Назва } \\
\text { матеріалу }\end{array}$} & \multirow{3}{*}{$\begin{array}{c}\text { Назва } \\
\text { клею }\end{array}$} & \multicolumn{5}{|c|}{ Руйнівне зусилля, кГс } & \multirow{3}{*}{$\begin{array}{l}\text { Сере- } \\
\text { днє } \\
\text { всіх } \\
\text { зраз- } \\
\text { ків, } \\
\text { кГс }\end{array}$} & \multirow{3}{*}{$\begin{array}{c}\text { Міц- } \\
\text { ність } \\
\text { під час } \\
\text { розтя- } \\
\text { гуван- } \\
\text { ня, } \\
\text { КГс/см }\end{array}$} \\
\hline & & & \multicolumn{5}{|c|}{ Номер зразків } & & \\
\hline & & & 1 & 2 & 3 & 4 & 5 & & \\
\hline 6.2 & $\begin{array}{l}\text { Папір крейдований } \\
350 \text { г/м² - подвій- } \\
\text { ний зразок }\end{array}$ & Без клею & 26,9 & 27,1 & 26,9 & 27,3 & 27,3 & 27,1 & 18,07 \\
\hline 6.3 & $\begin{array}{l}\text { Папір крейдований } \\
350 \text { г/м² - склеєний } \\
\text { зразок }\end{array}$ & $\begin{array}{c}\text { PLAKAL } \\
\text { Batch } 6602\end{array}$ & 28,7 & 28,5 & 28,5 & 28,3 & 28,5 & 28,5 & 19,0 \\
\hline 6.4 & $\longrightarrow »-$ & $\begin{array}{c}\text { Термоклей } \\
\text { Tecnomelt } 3660\end{array}$ & 29,2 & 29,3 & 29,2 & 29,3 & 29,5 & 29,3 & 19,53 \\
\hline 6.5 & $\longrightarrow »-$ & $\begin{array}{c}\text { Термоклей Smift } \\
\text { therm } 8028\end{array}$ & 29,1 & 29,2 & 29,6 & 28,8 & 28,8 & 29,1 & 19,4 \\
\hline 6.6 & $\longrightarrow »$ & $\begin{array}{c}\text { ПВАД ДФ } \\
51 / 15 В\end{array}$ & 30,5 & 30,5 & 30,5 & 30,6 & 30,4 & 30,2 & 20,13 \\
\hline 6.7 & $\longrightarrow »-$ & ПВАД 51-П & 30,0 & 30,2 & 30,0 & 30,4 & 30,4 & 30,2 & 20,13 \\
\hline 7.1 & $\begin{array}{l}\text { Картон хром-ерзац } \\
\text { товщина 0,3 мм - } \\
\text { одиничний зразок }\end{array}$ & Без клею & 8,8 & 8,9 & 8,8 & 8,8 & 8,8 & 8,82 & 5,89 \\
\hline 7.2 & $\begin{array}{l}\text { Картон хром-ерзац } \\
\text { товщина 0,3 мм - } \\
\text { подвійний зразок }\end{array}$ & Без клею & 17,2 & 17,3 & 17,2 & 17,4 & 17,3 & 17,28 & 11,52 \\
\hline 7.3 & $\begin{array}{l}\text { Картон хром-ерзац } \\
\text { товщина 0,3 мм - } \\
\text { склеєний зразок }\end{array}$ & $\begin{array}{c}\text { PLAKAL } \\
\text { Batch } 6602\end{array}$ & 18,9 & 18,8 & 18,9 & 18,7 & 18,9 & 18,84 & 12,56 \\
\hline 7.4 & $\longrightarrow »-$ & $\begin{array}{c}\text { Термоклей } \\
\text { Tecnomelt } 3660\end{array}$ & 20,2 & 20,4 & 20,3 & 20,2 & 20,0 & 20,22 & 13,48 \\
\hline 7.5 & -»- & $\begin{array}{c}\text { Термоклей Smift } \\
\text { therm } 8028\end{array}$ & 20,0 & 20,2 & 20,2 & 20,0 & 20,1 & 20,1 & 13,40 \\
\hline 7.6 & $\longrightarrow »-$ & $\begin{array}{c}\text { ПВАД ДФ } \\
51 / 15 В\end{array}$ & 22,7 & 22,8 & 22,8 & 22,7 & 22,6 & 22,72 & 15,15 \\
\hline 7.7 & -»- & ПВАД 51-П & 22,3 & 22,3 & 22,4 & 22,3 & 22,3 & 22,32 & 14,88 \\
\hline
\end{tabular}

розрахунковими результатами мали б відрізнятися на подвійну величину.

Аналізуючи показники міцності одиничних та подвійних зразків під час розтягування та в момент руйнування, отримані в результаті експериментальних досліджень, необхідно відзначити відмінність зусиль руйнування одиничних та подвійних зразків, які не мають пропорційних цифрових відображень, - точних, або наближених до точних подвійних величин. Відхилення складають від 1,91\% (для крейдованого паперу масою 150 г/м²) до 41,77\% (для крейдованого паперу масою

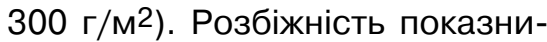
ків міцності для досліджуваних матеріалів відтворена на графіку рис. 1. 
Запис на цифрову відеокамеру процесу руйнування на розривній машині зразків поліграфічних матеріалів, відібраних для експериментів, та перегляд процесу в уповільненому режимі виявив неодночасність руйнування подвійних зразків, що вплинуло на числові показники та їх значну розбіжність.

Незважаючи на щільність затискання в розривній машині та паралельність розташування в затискачах зразків досліджуваних матеріалів, руйнування внутрішньої структури одного з двох зразків у процесі розтягування відбувалося 3 випередженням. Можна припустити, що обкладинки, конструктивно виготовлені з подвійного аркуша палітурного матеріалу, зношуються під час тривалого використання та дії руйнівних експлуатаційних чинників у пропорціях наближених до отриманих експериментальних результатів для кожного із застосованих матеріалів.
Для визначення особливостей застосування палітурних клеїв при виготовленні інтегральних та інших спрощених обкладинок, що збільшують міцність клеєних конструктивних елементів обкладинок, при виготовленні яких використовується папір різною масою та картон хром-ерзац, проведено порівняльні дослідження міцності зразків палітурних матеріалів та палітурних клеїв, найбільш вживаних при виготовленні книжково-журнальних оправ. Визначені показники міцності створять часткову базу для вибору матеріалів та конструкцій обкладинок, що забезпечать необхідну жорсткість та експлуатаційну стійкість із мінімальними економічними витратами.

За підсумками отриманих результатів випробувань, що відтворюють показники максимальних зусиль руйнування та розриву одиничних, подвійних та склеєних зразків матеріалів, із яких можуть бути виготовлені книжково-журнальні обкладинки 3 різними конструкційними особливостями, побудовано діаграми (рис. 2-8).

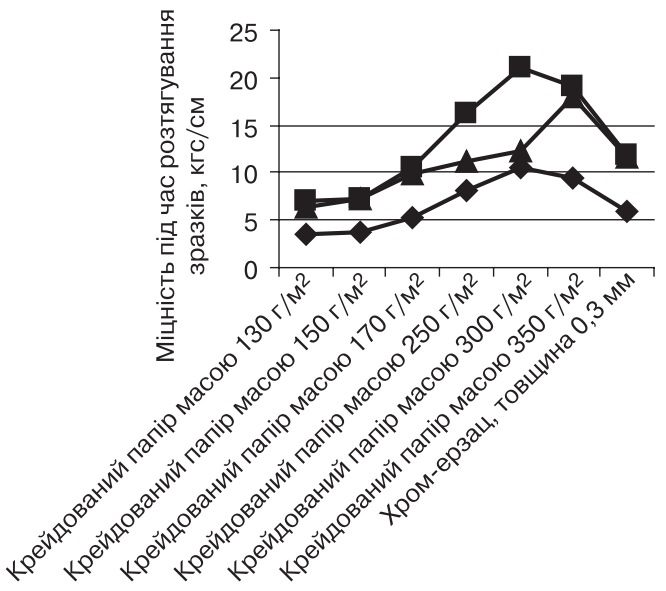

— Показники міцност одиничних зразків

- Розрахункові показники міцності подвійних зразків

- Експериментальні показники міцності подвійних зразків

Зразки матеріалів

Рис. 1. Відхилення показників міцності одиничних та подвійних зразків матеріалів розрахункових та експериментальних величин 
Різниця показників міцності подвійних та склеєних зразків - Показники міцності склеєних зразків Показники міцності подвійних зразків - Показники міцності одиничних зразків

PLAKA

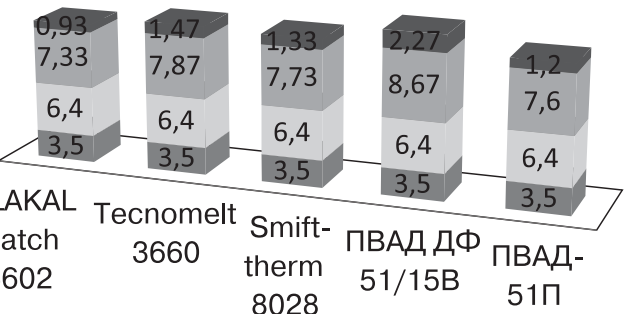

Рис. 2. Показники міцності під час розтягування зразків крейдованого паперу масою 130 г/м² - одиничних, подвійних та склеєних (табл. 1, поз. 1.1-1.7)

Різниця показників міцності подвійних та склеєних зразків Показники міцності склеєних зразків

Показники міцності подвійних зразків П Показники міцності одиничних зразків

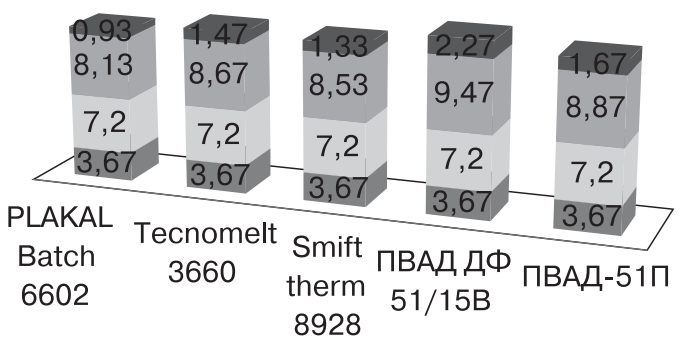

Рис. 3. Показники міцності під час розтягування зразків крейдованого паперу масою 150 г/м² - одиничних, подвійних та склеєних

(табл. 1, поз. 2.1-2.7)

- Різниця показників міцності подвійних та склеєних зразків Показники міцності склеєних зразків Показники міцності подвійних зразків - Показники міцності одиничних зразків

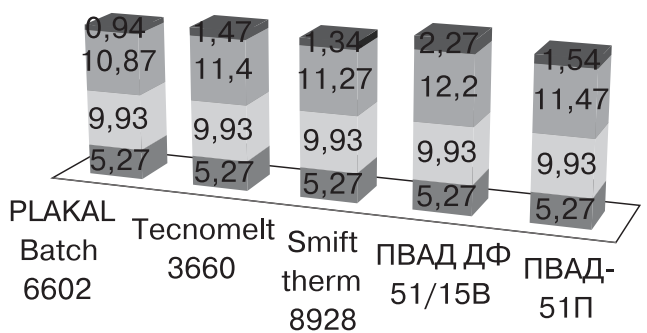

Рис. 4. Показники міцності під час розтягування зразків крейдованого паперу масою 170 г/м2 - одиничних, подвійних та склеєних (табл. 1, поз. 3.1-3.7) 
Різниця показників міцності подвійних та склеєних зразків

Показники міцності склеєних зразків

Показники міцності подвійних зразків

Показники міцності одиничних зразків

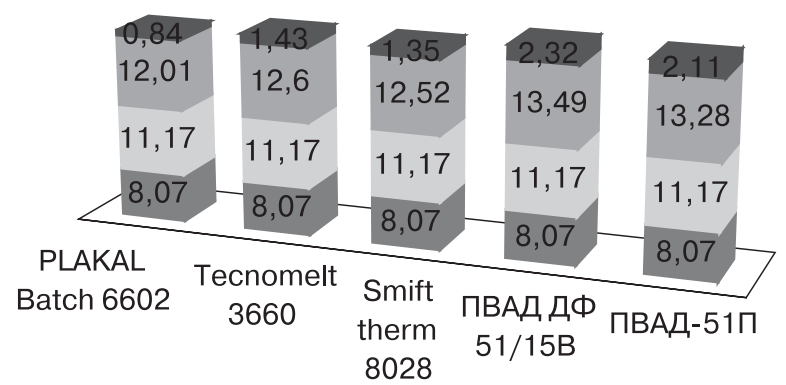

Рис. 5. Показники міцності під час розтягування зразків крейдованого паперу масою 250 г/м² - одиничних, подвійних та склеєних

(табл. 1, поз. 4.1-4.7)

Різниця показників міцності подвійних та склеєних зразків

Показники міцності склеєних зразків

Показники міцності подвійних зразків

Показники міцності одиничних зразків

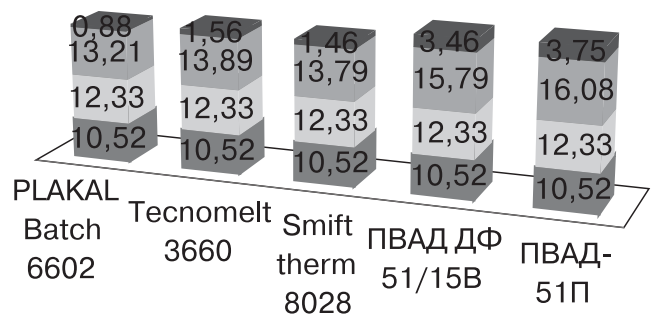

Рис. 6. Показники міцності під час розтягування зразків крейдованого паперу масою 300 г/м² - одиничних, подвійних та склеєних (табл. 1, поз. 5.1-5.7)

口 Різниця показників міцності подвійних та склеєних зразків - Показники міцності склеєних зразків

Показники міцності подвійних зразків

— Показники міцності одиничних зразків

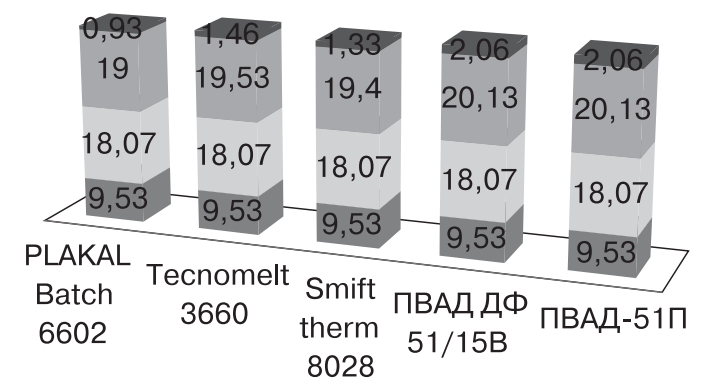

Рис. 7. Показники міцності під час розтягування зразків крейдованого паперу масою 350 г/м² - одиничних, подвійних та склеєних

(табл. 1, поз. 6.1-6.7) 


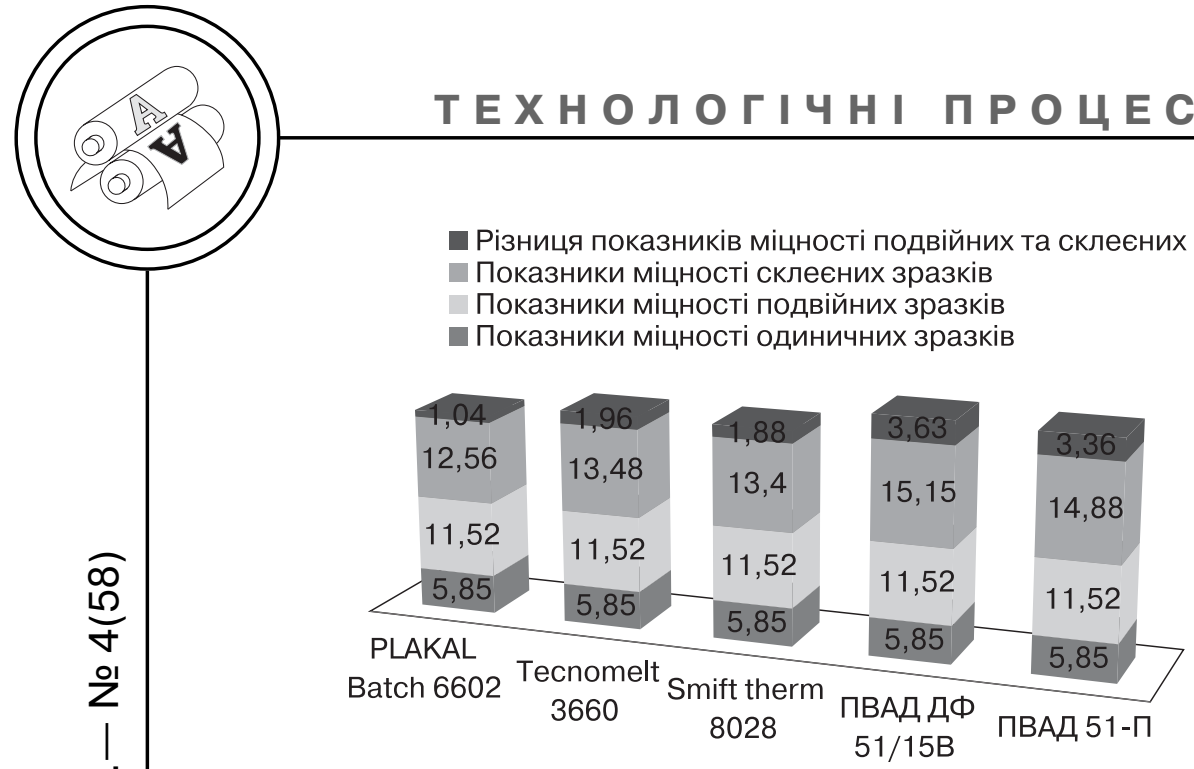

Рис. 8. Показники міцності під час розтягування зразків картону хромерзац товщиною 0,3 мм - одиничних, подвійних та склеєних (табл. 1, поз. 7.1-7.7)

Із розвитком сучасних технологій виготовлення книжковожурнальної продукції в традиційних жорстких та м'яких оправах підвищуються вимоги до оправ, які відповідали б умовам ресурсозберігальних технологій залучення мінімальної кількості палітурних матеріалів з одночасним забезпеченням довготривалості використання, міцності та малої ваги.

Одним із критеріїв забезпечення таких переваг виробленої друкованої продукції є підвищувані вимоги до якості проклейки в процесі виготовлення оправ і до надійності скріплення з ними блоків паперу різного типу.

Дослідження однотипних матеріалів на міцність під час розтягування зразків виявили відмінність впливу палітурних клеїв, що були відібрані для експериментів, на показники міцності.

Із урахуванням стабільних властивостей термоклеїв, їх відмінного прилипання, забезпечення надійного склеювання, утво- рення клейової плівки високої еластичності при виготовленні обкладинок, відповідно до отриманих результатів, максимальні порівняльні характеристики впливу на міцність склеювання зразків крейдованого паперу і картону дали змогу виявити полівінілацетатні дисперсії.

Дисперсії ПВА характеризуються високою адгезією до різних поверхонь та стійкістю до впливу зовнішніх факторів. Клейове з'єднання за короткий час досягає високого рівня міцності за рахунок ефективного змочування та проникнення всередину матеріалу, забезпечує швидке висихання.

Графіки порівняльних характеристик зображені на рис. 9.

Аналіз графіків показників міцності відтворює поступове збільшення цифрових характеристик міцності зразків крейдованого паперу відносно збільшення маси паперу та зразка картону хром-ерзац, виготовленого з макулатури, а також вплив різних 
видів палітурних клеїв на показники міцності, що створює часткову інформаційну базу для їх доцільного використання.

Сумарний вплив структури матеріалів та клеїв, якими склеєні зразки паперу й картону, виявив максимальні показники міцності під час розтягування в склеєних зразків крейдованого паперу масою 350 г/м², крейдованого паперу масою 300 г/м² та картону хром-ерзац товщиною 0,3 мм, що склеєні клеєм ПВАД ДФ 51/15В.

Разом з тим, порівняльні характеристики міцності під час розтягування одиничних зразків палітурних матеріалів та тотожних подвійних склеєних зразків виявили інші залежності збільшення міцності, що відтворені в табл. 2 та на графіку на рис. 10.
Максимальні показники міцності (практично однакові) зафіксовані в зразках крейдованого паперу масою 150 г/м² $(2,58)$ та картону хром-ерзац товщиною 0,3 мм (2,57). Це свідчить про те, що при виборі компонентів для виготовлення обкладинок (наприклад, з приклеєними крайками) необхідна жорсткість і міцність обкладинки може бути забезпечена завдяки застосуванню паперу з нижчими показниками маси, ніж у такої ж обрізної обкладинки.

\section{Висновки}

Із урахуванням необхідності виготовлення ресурсозберігальних та ергономічних книжковожурнальних обкладинок у сучасному висококонкурентному

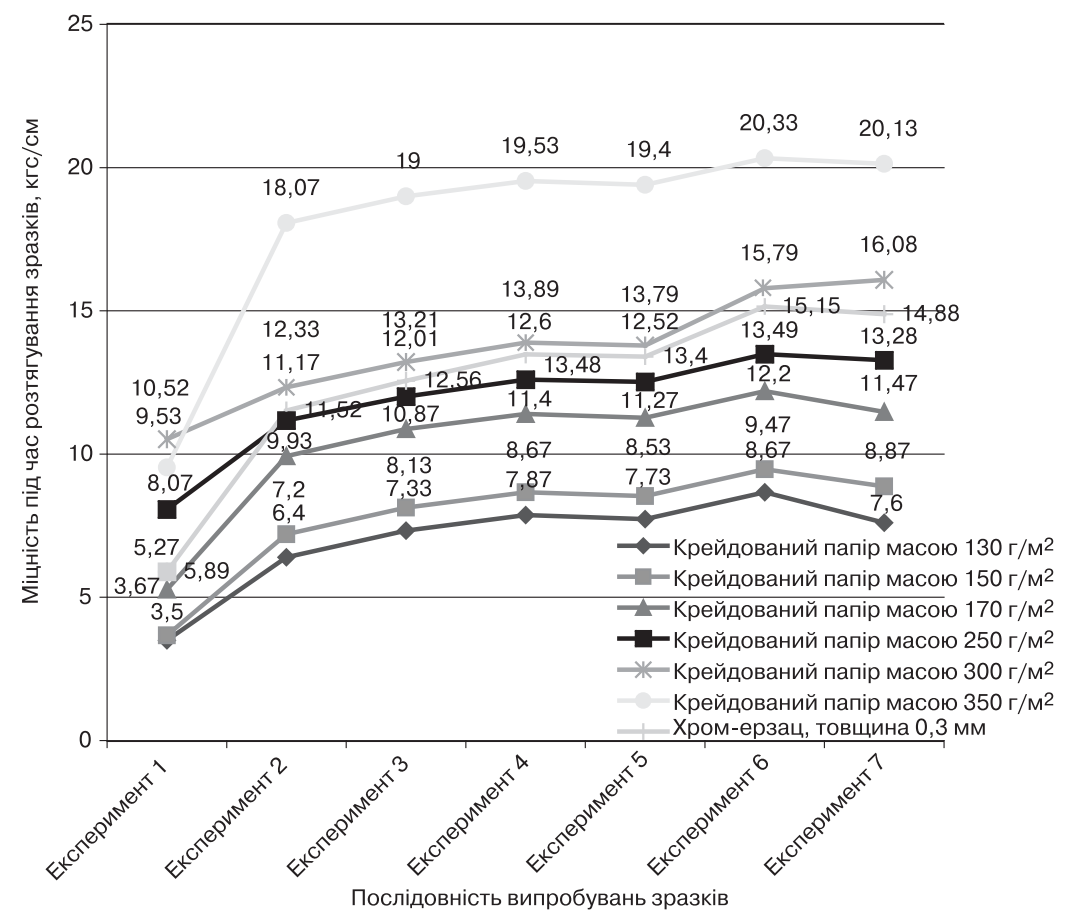

Рис. 9. Порівняльні графіки показників міцності під час розтягування зразків палітурних матеріалів одиничних, подвійних та склеєних 


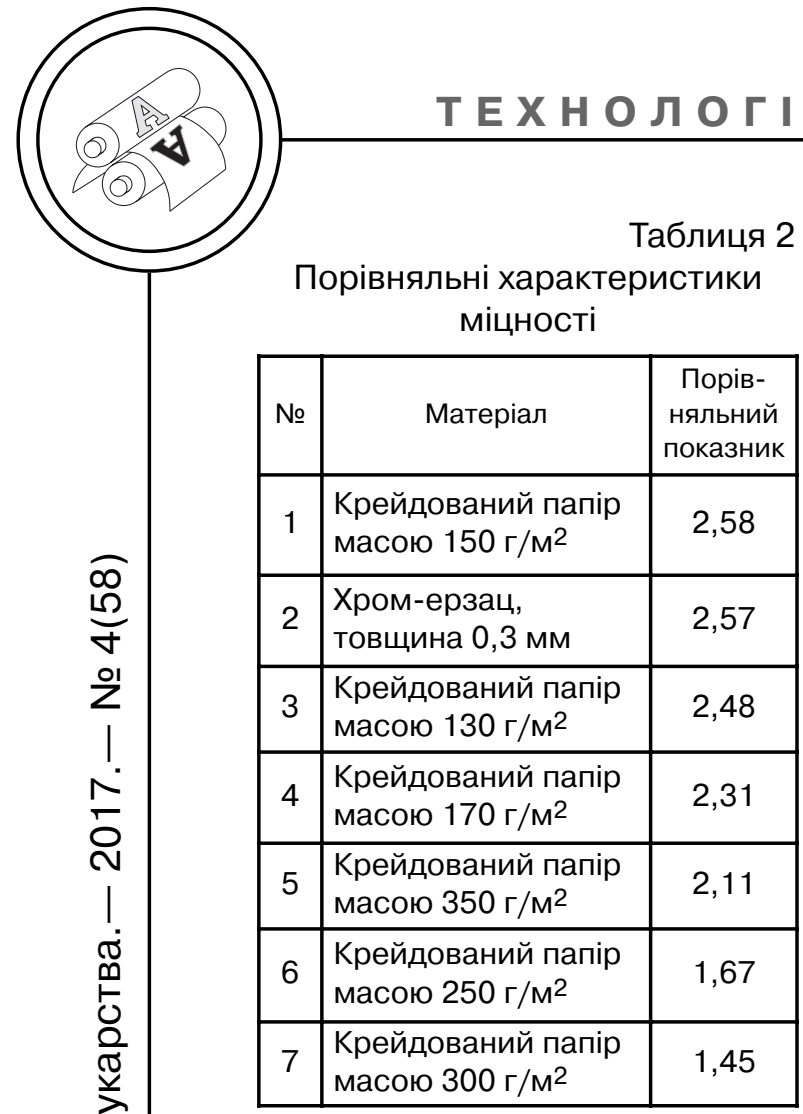

середовищі розповсюдження поліграфічної продукції і формування споживчої ціни, аналіз прове- дених досліджень дав змогу визначити залежності змін у міцності одиничних, подвійних та склеєних зразків палітурних матеріалів. Отримані результати мають прикладне значення при підбиранні компонентів виготовлення оправ $з$ мінімізованими економічними показниками.

Наведені в таблицях та на графіках експериментів чисельні показники міцності сприяють створенню додаткових можливостей для виготовлення нових оправ із використанням обмеженої кількості технологічних процесів. Вибір складових для таких оправ (з урахуванням показників міцності) забезпечить їх високі експлуатаційні характеристики та необхідний рівень образотворчого відтворення.

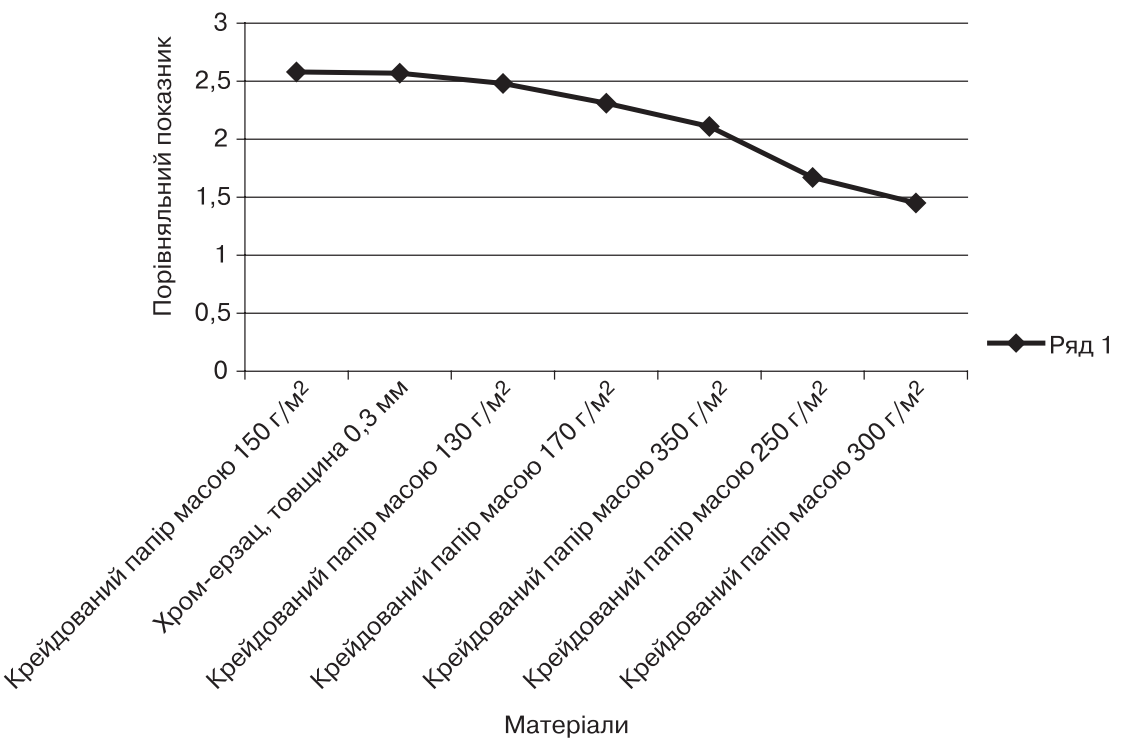

Рис. 10. Порівняльні графіки показників міцності під час розтягування одиничних та подвійних склеєних зразків палітурних матеріалів 


\section{Список використаної літератури}

1. Воробьев Д. В. Технология брошюровочно-переплетных процессов / Д. В. Воробьев, И. А. Дубасов, Ю. М. Лебедев. М.: Книга, 1989. 392 с.

2. Пат. 32803 А України, B42D 3/00 Конструкція книжково-журнальної обкладинки і спосіб її виготовлення / Мартинюк М. С., Гавенко С. Ф., Кулік Л. Й. Заявл. 28.04.98; Опубл. 15.02.2001. Бюл. № 1.

3. Пат. 25601А України, МПК 6B 42D 3/00. Конструкція книжковожурнальної обкладинки і спосіб її виготовлення / Мартинюк М. С., Гавенко С. Ф., Кулік Л. Й. Заявл. 14.04.98; Опубл. 25.12.98. Бюл. № 6.

4. М. Шарифуллин. Интегральный переплет / М. Шарифуллин // КомпьюАрт. 2007. № 11.

5. Гавенко С. Конструкція книги / С. Гавенко, Л. Кулік, М. Мартинюк. Львів: Фенікс, 1999. 36 с.

6. Лазаренко Е. Т. Поліграфічні матеріали / Ю. Ц. Жидецький, Е. Т. Лазаренко, Н. Д. Лотошинська. Львів: Афіша. 2000.

7. COУ 22.2-02477019-15:2010 «Поліграфія. Обкладинки та палітурки». Київ: Держкомтелерадіо України, 2010.

8. СОУ 22.2-02477019-09:2007 «Видання. Видавниче оформлення і поліграфічне виконання. Номенклатура показників якості». Київ: Держкомтелерадіо України, 2007.

9. Мартинюк М. С. Дослідження технологічних та експлуатаційних властивостей палітурних матеріалів / М. С. Мартинюк // Наукові записки. Львів: УАД, 1998. Вип. 1. С. 40-42.

10. Мартинюк М. Оптимізація процесу розкрою покривного матеріалу для палітурок методом математичного програмування / М. Мартинюк // Поліграфія і видавнича справа. 1999. № 35. С. 170-172.

11. Jonh Peacock. Book production. BLUEPRINT: The publishers association, $1995.400 \mathrm{p}$.

12. Палюх О. О. Дослідження клеючої здатності окремих видів клеїв для виготовлення книжкових оправ із палітурних матеріалів з різними технологічними властивостями / О. О. Палюх // Технологія і техніка друкарства. Київ: КПІ ім. І. Сікорського ВПІ, 2017. № 3. С. 43-52. Режим доступу: http://ttdruk.vpi.kpi.ua/editor/submission/124254.

\section{References}

1. Vorob'ev, D. V. \& Dubasov, I. A. \& Lebedev, Yu. M. (1989). Tekhnologiya broshyurovochno-perepletnykh protsessov. Moscow: Kniga, 392 [in Russian].

2. Martyniuk, M. S. \& Havenko, S. F. \& Kulik, L. Y. Konstruktsiia knyzhkovozhurnalnoi obkladynky i sposib yii vyhotovlennia // Patent UA № 32803 A. Publish 15.02.2001 [in Ukrainian].

3. Martyniuk, M. S. \& Havenko, S. F. \& Kulik, L. Y. Konstruktsiia knyzhkovozhurnalnoi obkladynky i sposib yii vyhotovlennia // Patent UA № 25601A. Publish 25.12.98 [in Ukrainian].

4. Sharifullin, M. (2007). Integral'nyy pereplet. Journal of Komp'yuArt, 11 [in Russian].

5. Havenko, S. \& Kulik, L. \& Martyniuk, M. (1999). Konstruktsiia knyhy. Lviv: Feniks, 36 p. [in Ukrainian].

6. Zhydetskyi, Yu. Ts. \& Lazarenko, E. T. \& Lotoshynska, N. D. (2000). Polihrafichni materialy. Lviv: Afisha [in Ukrainian].

7. National standards of Ukraine. (2010). SOU 22.2-02477019-15:2010. Polihrafiia. Obkladynky ta paliturky. Kyiv: Derzhkomteleradio Ukrainy [in Ukrainian]. 
8. National standards of Ukraine. (2007). SOU 22.2-02477019-09:2007. Vydannia. Vydavnyche oformlennia i polihrafichne vykonannia. Nomenklatura pokaznykiv yakosti. Kyiv: Derzhkomteleradio Ukrainy [in Ukrainian].

9. Martyniuk, M. S. (1998). Doslidzhennia tekhnolohichnykh ta ekspluatatsiinykh vlastyvostei paliturnykh materialiv. Journal of Naukovi zapysky, 1, 40-42. Lviv: UAD [in Ukrainian].

10. Martyniuk, M. (1999). Optymizatsiia protsesu rozkroiu pokryvnoho materialu dlia paliturok metodom matematychnoho prohramuvannia. Journal of Polihrafiia i vydavnycha sprava, 35, 170-172 [in Ukrainian].

11. Peacock, Jonh (1995). Book production. BLUEPRINT: The publishers association, 400 p. [in English].

12. Paliukh, O. O. (2017). Doslidzhennia kleiuchoi zdatnosti okremykh vydiv kleiv dlia vyhotovlennia knyzhkovykh oprav iz paliturnykh materialiv z riznymy tekhnolohichnymy vlastyvostiamy. Journal of Tekhnolohiia i tekhnika drukarstva, 3, 43-52. Retrieved from http://ttdruk.vpi.kpi.ua/editor/submission/124254. DOI: https://doi.org/10.20535/2077-7264.3(57).2017.124254 [in Ukrainian].

Учитывая необходимость изготовления ресурсосберегающих и эргономических книжно-журнальных обложек в современной высококонкурентной среде распространения полиграфической продукции и формирования потребительской цены, анализ проведенных исследований определил зависимости изменений в прочности единичных, двойных и склеенных образцов переплетных материалов, имеющих прикладное значение при подборе компонентов изготовления обложек с минимизированными экономическими показателями.

Ключевые слова: книжные обложки; переплет; усилия растяжения; прочность материалов; разрушение образцов.

Taking into consideration the necessity of the production of the resource-saving and ergonomic book and magazine covers under conditions of the recent highly competitive environment of the printed products distribution and the consumer pricing, the analysis of the conducted research identified the relation the changes in the indexes of strengthen capacity of single- and two-ply binding materials samples as well as pasted ones. These findings have applied relevance while selecting the covering components for their production with minimized economic indicators.

Keywords: book covers; cover; flexible binding; tensile load; strength of materials; destruction of samples. 